\title{
La pragmàtica de la interllengua en estudiants polonesos de català com a LE: una primera aproximació a l'adquisició dels oferiments i les peticions ${ }^{1}$
}

\author{
Joana Catany Blázquez ${ }^{1,2}$ \\ Universitat Adam Mickiewicz de Poznańn \\ joana.catany@gmail.com
}

\author{
Maria del Mar Vanrell ${ }^{2}$ \\ Universitat de les Illes Balears ${ }^{2}$ \\ mm.vanrell@uib.cat
}

Rebut: 28 d'agost de 2021

Acceptat: 2 de novembre de 2021

\section{Resum}

Aquest article analitza l'adquisició de les estratègies de cortesia associades amb les peticionsiels oferiments. Vint-i-tresinformants, 13 parlants de català com a LE amb el polonès com a L1 i 10 parlants de català com a L1 (grup de control), varen realitzar un qüestionari basat en la tasca de compleció del discurs. Els resultats demostren que els factors amb un efecte més important sobre les variables dependents són l'acte de parla i factors pragmàtics com la distància social i el cost de l'acció verbal. La diferència entre parlants nadius i aprenents de català no és una diferència de naturalesa, sinó de grau. Així doncs, veim que els informants polonesos recorren més sovint a determinades variables com ara l'ús d'interrogatives o la dixi de persona per suavitzar determinades accions mitjançant la cortesia, mentre que d'altres variables són usades en la mateixa mesura pels dos grups d'informants, tant pels aprenents de català com pels parlants amb el català com a L1. Concloem que des del punt de vista pragmàtic la interllengua constitueix un sistema dinàmic, amb un grau alt de variabilitat, però, tanmateix, basat en regles, provinents de la llengua inicial o no.

Paraules clau Català LE, polonès L1, oferiments, peticions, estratègies de cortesia

\begin{abstract}
This paper analyses the acquisition of politeness strategies associated to offers and requests. Twenty-three subjects, $13 \mathrm{~L} 1$ Polish Catalan learners and 10 Catalan L1 speakers (used as control group), were asked to complete a questionnaire based on the Discourse Completion Task. The results show that the relevant factors are the illocutionary act and pragmatic factors like social distance and cost of the act. Differences between Catalan learners and native speakers are not in nature but only in degree. Thus, Polish Catalan learners resort more often to specific variables such as the use of interrogatives or the pronominal form to soft the illocutionary force of speech acts, whereas other variables are used by both Catalan learners and native speakers. We conclude that from a pragmatic perspective the interlanguage is a dynamic system, highly variable, but rule-governed.
\end{abstract}

\section{Key words}

Catalan learners, L1 Polish, offers, requests, politeness strategies

1 Agraïments: aquest article està basat en el treball de fi de grau Oferiments i peticions: un estudi contrastiu entre el català $i$ el polonès sobre les estratègies de cortesia, presentat el setembre de 2019 a la Universitat de les Illes Balears per la primera autora i tutelat per la segona autora. Agraïm als membres del tribunal (Lluís BarcelóCoblijn, Rosa Calafat Vila i Joan Melià i Garí) els seus comentaris, que han ajudat a millorar substancialment aquest article. Maciej Rewucki també mereix un agraïment especial pel suport ofert a l'hora de trobar informants. També volem donar les gràcies a dos revisors anònims i a la cap de secció de recerca, Elga Cremades, pel temps invertit a llegir i comentar el manuscrit. Finalment, els informants polonesos i catalans mereixen una menció especial per haver participat, de manera totalment desinteressada, en la recerca. 


\section{Introducció}

Aquest article se centra en l'anàlisi de la pragmàtica de la interllengua, concretament en les estratègies de cortesia que desenvolupen els aprenents de català com a llengua estrangera (LE) amb el polonès com a llengua inicial (L1). Mentre que la pragmàtica de la interllengua és un aspecte prou estudiat en aprenents d'anglès o d'espanyol, encara comptam amb pocs treballs que estudiïn aquest aspecte en relació amb el català. Aquest treball, doncs, pretén contribuir a omplir aquest buit descriptiu i plantejar noves preguntes a les quals pugui donarse resposta en el futur.

\subsection{La cortesia lingüística: peticions i oferiments en català i en polonès}

En el camp d'estudi de la pragmàtica, els estudis de cortesia se centren a descriure i explicar la manera en què determinades tries lingüístiques afecten i es veuen afectades per les relacions socials que existeixen entre els interlocutors (Escandell-Vidal, Estebas-Vilaplana i Vanrell, en procés de revisió). En parlar de cortesia, podem referir-nos o bé a un conjunt de normes socials o a un conjunt d'estratègies conversacionals. D'ara endavant ens atendrem al segon sentit, tot i que, com és evident, la cortesia entesa com a norma social també té conseqüències clares en la tria de certes unitats lingüístiques. A l'hora d'intentar aconseguir un determinat objectiu mitjançant la comunicació verbal, doncs, l'emissor ha de tenir en compte que el seu enunciat no només s'ha d'adaptar als seus objectius, sinó també a la posició i funció social del destinatari. Per això, per tal de mantenir una relació cordial és important utilitzar correctament tots els recursos del llenguatge, a fi d'evitar o mitigar les possibles friccions entre els objectius de l'emissor i els del destinatari del missatge. Això explica que la cortesia i el principi de cooperació (Grice, 1975) sovint representin forces oposades, ja que existeix una clara diferència motivada pel tipus de discurs i pels seus objectius. D'aquesta manera, un intercanvi és interaccional quan el que importa és el manteniment de les relacions socials i, per tant, venç la cortesia (1), mentre que un intercanvi transaccional té a veure amb la transmissió eficaç d'informació i per tant, els principis conversacionals hi tenen prioritat (2) (Escandell-Vidal 1996/2006):

(1) Les dades del disc dur són irrecuperables.

(2) Hem escanejat el disc dur amb tots els programes de diagnòstic i recuperació disponibles i hem intentat accedir a les dades des de diferents ordinadors i sistemes operatius. De moment, no hem tengut èxit. Convé que comenceu a fer-vos a la idea que potser no hi podreu tornar a accedir. ${ }^{2}$

Durant els darrers 50 anys s'han desenvolupat diferents models sobre la cortesia lingüística, com ara el de Robin Lakoff, el de Geoffrey N. Leech i el de Penelope Brown i Stephen C. Levinson. Aquest treball se cenyirà als dos darrers models, perquè són els que permeten entendre millor la tria de factors inclosos en el disseny experimental. El model de Leech (1983) parteix de la idea que la cortesia relaciona l'adequació entre els enunciats i la distància social existent entre els interlocutors. D'aquesta manera, la cortesia valorarà el cost-benefici que suposi realitzar una determinada acció per a l'emissor o el destinatari. Així doncs, quan hi hagi més cost per al destinatari l'acció serà més descortesa, i quan hi hagi més cost per a l'emissor i més benefici per al destinatari, l'acció serà més cortesa. Leech (1983: 83) indica que alguns actes il-locutius, per exemple les peticions, són inherentment descortesos. En canvi d'altres, com per exemple els oferiments, són inherentment cortesos. Leech (1983: 84) distingeix, també, dos tipus de cortesia: la cortesia positiva i la cortesia negativa. La cortesia positiva consisteix a maximitzar la cortesia dels actes il-locutius cortesos, i la cortesia negativa consisteix a minimitzar la dels actes il-locutius descortesos. La cortesia negativa sol ser imprescindible per mantenir les bones relacions, mentre que la cortesia positiva és secundària. 
Brown i Levinson (1987) parteixen del supòsit que la cortesia és una eina per controlar l'agressivitat social i mantenir les bones relacions socials. Aquest model també es basa en el fet que la comunicació té com a objectiu ser eficaç. En aquest sentit, la comunicació està subjecta al principi de cooperació de Grice, entès com el marc socialment neutre on es desenvolupen els intercanvis comunicatius, $i$ en pressuposa la racionalitat i eficàcia. Als participants d'un acte comunicatiu els caracteritzen dos trets essencials que expliquen el seu comportament durant l'intercanvi d'informació: la racionalitat i la imatge pública. La racionalitat, lligada al principi de cooperació de Grice, és la capacitat humana de raonar. Aquesta capacitat racional ens permet determinar els passos i les eines necessaris per aconseguir un propòsit. En canvi, la imatge pública (en anglès, face), lligada a la cortesia, és el que cada individu d'una societat reclama, posseeix i defensa, és a dir, cert prestigi. La imatge pública té dues vessants: la negativa i la positiva. La negativa és la voluntat de tenir llibertat d'acció, i la positiva és la voluntat d'apreciació per part dels altres. El que varia d'una cultura a una altra són els elements particulars que conformen en cada cas la imatge pública desitjable: el concepte d'imatge pública i els efectes que té damunt els comportaments socials són universals. També hi pot haver accions que amenacin la imatge pública (en anglès, face-threatening acts): en aquests casos, llevat que realment es desitgi amenaçar la imatge pública, l'emissor normalment procura suavitzar l'acció mitjançant la cortesia. El nivell de cortesia que s'ha d'emprar depèn de tres factors: el poder relatiu del destinatari respecte de l'emissor; la distància social, que inclou el grau de familiaritat i contacte entre els interlocutors; i el grau d'imposició d'un determinat acte respecte de la imatge pública. El risc potencial que comporta una determinada acció que amenaci la imatge pública (AAIP) es calcula sumant els valors d'aquests factors. Per tant, la suma d'aquests factors permet calcular quina repercussió s'espera d'una AAIP i, si es desitja, triar les estratègies de cortesia destinades a mitigar el perill.

Que sapiguem, aplicats al català, només hi ha dos treballs que analitzin les peticions i els oferiments, dos tipus d'actes de parla que comporten diferents graus d'amenaça a la imatge pública. Astruc, Vanrell i Prieto (2016) investigaren la relació existent entre la cortesia i la tria del patró entonatiu. Quinze parlants de català central participaren en una tasca de compleció del discurs, que generà peticions i oferiments en situacions controlades pel nivell de poder, distància i cost de l'acció (Leech, 1983; Brown i Levinson, 1987). Les dades resultants s'analitzaren mitjançant la prosòdia i la pragmàtica, i els resultats mostren que els paràmetres amb un efecte més important en el patró entonatiu utilitzat són la distància social i el cost de l'acció. En canvi, el poder social sembla que no va tenir cap efecte important en l'ús d'un determinat patró entonatiu. Així doncs, segons els resultats, les peticions es formulen més freqüentment mitjançant una interrogació (84\%) que els oferiments $(66,9 \%)$, i tendeixen a produir-se amb formes formals per adreçar-se a l'interlocutor (vostè) i llenguatge indirecte, especialment quan hi ha més distància entre els parlants i més poder del receptor en relació amb l'emissor. Finalment, les peticions es produeixen més sovint amb contorns ascendents (57\%) que els oferiments (39\%). L'estudi conclou que cal tenir en compte els factors de cortesia en la descripció dels diferents patrons entonatius que poden usar les llengües. Pizà i Vanrell (2018), al seu torn, analitzaren el sistema de tractaments en el català de Mallorca. Mitjançant una adaptació de la tasca dissenyada per Astruc, Vanrell i Prieto (2016) es varen recollir 864 enunciats (32 contextos pragmàtics x 27 informants). Les dades resultants mostren que l'ús del tractament informal tu és majoritari en les tres localitats estudiades, Palma, Montuïri i Llucmajor, tot i que les formes formals vós i vostè també es fan servir, però en menor mesura. Els paràmetres que produeixen un efecte més important en la tria del tractament són l'acte de parla (peticions o oferiments), l'edat del destinatari del missatge i els factors pragmàtics de la distància i el poder socials. En resum, es pot dir que les peticions, una edat més avançada del destinatari, així com més distància social entre els parlants i més poder social de l'interlocutor desencadenen un increment en l'ús dels pronoms de cortesia (vós i vostè). 
Pel que fa a les peticions en polonès, Wierzbicka (2003) afirma que la forma interrogativa no s'usa gaire: formular una pregunta seria equivalent a qüestionar la bona predisposició dels interlocutors a cooperar i, per tant, posaria en dubte la bona relació entre l'emissor i el receptor. La manera més típica de formular una petició en polonès, doncs, és mitjançant el mode imperatiu. Construccions gramaticals presents en la formulació de peticions formals o informals són els diminutius, les fórmules de tractament ty (en català: $t u$ ) per a menys distància i Pan/Pani (en català: senyor/senyora) per a més distància, i el verb performatiu prosić (en català: demanar). Els diminutius també s'empren per disminuir el cost de l'acció i estrènyer les relacions entre l'emissor i el receptor. Finalment, el verb performatiu prosić s'empra per augmentar la cortesia a l'hora d'adreçar-se a desconeguts, mantenir l'atenció de l'oient, animar algú a començar una activitat o expressar sorpresa, ironia o menyspreu. Segons Wierzbicka (2003), els oferiments en polonès tampoc s'expressarien amb la modalitat interrogativa. Formular una interrogació implicaria mostrar interès pels desitjos i sentiments de l'interlocutor, quan realment, segons l'hospitalitat polonesa, en un oferiment de menjar o beguda, per exemple, l'amfitrió ha d'intentar que el convidat mengi i begui tant com sigui possible. L'amfitrió no admet un "no" per resposta, i si el convidat diu "no" ho diu per compromís (cortesia) i s'assumeix que en vol més.

\subsection{La interllengua dels aprenents}

En general s'assumeix que l'adquisició d'una llengua estrangera implica l'establiment d'una gramàtica que permetrà a l'aprenent aproximar-se a la llengua meta (LM). Aquesta gramàtica, que el parlant construeix a partir de determinats trets de la seva L1, de la generalització o simplificació de trets de la LM i també de canvis interns al propi sistema lingüístic, s'anomena interllengua (Selinker, 1972). Des d'aquest punt de vista l'aprenent dota d'estructura les dades lingüístiques disponibles i construeix un sistema internalitzat (Torres-Tamarit i Vanrell, 2021). La tasca dels investigadors, doncs, és descriure i explicar la trajectòria de desenvolupament que segueixen els aprenents de la LM a partir de la caracterització de la interllengua. Cal destacar que la interllengua emergeix quan l'aprenent produeix significat, no quan repeteix estructures de la LM en un context dirigit. L'altre aspecte important és que, per bé que la perspectiva de la interllengua s'ha aplicat sobretot a la sintaxi, la morfologia i la fonologia, és igualment aplicable a altres nivells de la representació lingüística com ara la pragmàtica o el lèxic.

Com ja s'ha dit, les regles que regeixen la interllengua poden ser degudes a factors diversos com la transferència de la L1, la simplificació de trets de la LM o desenvolupaments interns al sistema de la interllengua (Winford, 2002). El terme transferència s'ha usat amb diferents accepcions. Així doncs, mentre que Lado (1957) l'interpreta com l'ús d'elements o estructures de la L1 en la LM, la interpretació que en fa Odlin (1989: 27) és més àmplia i es refereix a les similituds i diferències entre la llengua meta i qualsevol altra llengua que s'hagi adquirit prèviament. També se sol distingir entre transferència positiva i transferència negativa. La transferència positiva emergeix quan la L1 i la LM estan emparentades i, per tant, els elements transferits des de la L1 són molt propers o idèntics als de la LM. En canvi, quan la L1 i la LM són distants, es parla de transferència negativa. La transferència des de la L1 pot ser de tot tipus: lèxica (per exemple brills en anglès com a transferència de l'alemany Brille 'ulleres', Winford, 2002), fonològica (els parlants d'àrab com a L1 aprenents de català substitueixen les vocals mitjanes per [i] i [u]: p[í]x, p[i]l-lícula, d[ú]s, Sánchez, 2005), sintàctica (Il n'est [sic] pas prendre le en francès com a transferència de l'estructura He doesn't take it, amb el clític sempre en posició postverbal, de l'anglès, Winford, 2002), etc. En canvi, no és tan clar que hi pugui haver transferència de tipus morfològic. En general, s'assumeix que n'hi pot haver en cas de llengües properes des del punt de vista tipològic (doge en anglès per transferència de l'alemany Hunde 'cans'). No obstant això, l'estratègia preferida dels aprenents sol ser simplificar la flexió de la llengua meta i emprar mitjans perifràstics per expressar-la (Winford, 2002). 
Dins el terme simplificació s'hi solen incloure diferents estratègies. Per exemple, com ja hem vist, la reducció de la morfologia de la llengua meta és un dels mitjans de simplificació més comuns. De vegades, però, es fa difícil distingir si es tracta de transferència de la L1 o de reducció. Per exemple, la substitució de les vocals mitjanes del català per les vocals altes [i]/ [u] en els aprenents de català L1 àrab pot entendre's com un cas de transferència, ja que el sistema vocàlic de l'àrab compta amb només 3 vocals (Torres-Tamarit i Vanrell, 2021), o com un cas de simplificació. Altres tipus de simplificació tenen com a objectiu la sistematització de la gramàtica de la llengua meta. És el que Meisel (1977) ha anomenat simplificació elaborada. Alguns exemples de simplificació elaborada són la compensació de la manca de morfologia amb mitjans perifràstics, com ara l'ús d'adverbis per manifestar el temps o un ordre de mots fix per distingir el subjecte de l'objecte, i estratègies com la generalització, com per exemple, l'ús de la terminació -ed en verbs irregulars com run 'córrer' o see 'veure' en anglès com a LE, etc. Algunes d'aquestes estratègies de simplificació elaborada són presents també en l'adquisició de la L1.

Els aprenents, però, no només adopten elements de la seva L1 o la LM a l'hora de comunicarse. També reajusten de manera creativa els recursos que usen i d'aquesta manera formulen $\mathrm{i}$ comproven hipòtesis amb relació a la gramàtica de la llengua meta (Winford, 2002). Molts d'aquests canvis semblen motivats per principis universals, restringits per l'estructura de la llengua en si mateixa. La principal motivació sembla ser la necessitat d'aconseguir regularitat i transparència en la gramàtica, és a dir, isomorfisme. Altres nocions com la de marcatge de determinades unitats o estructures (Eckman, 1977, 1985, 1991; Torres-Tamarit i Vanrell, 2021; Cicres i Llach, en procés de revisió) també es relacionen amb la facilitat i l'ordre amb què s'adquireixen.

\subsection{Objectiu i hipòtesi}

L'objectiu principal d'aquesta recerca és fer una primera aproximació al desenvolupament de la pragmàtica de la interllengua dels aprenents de català amb el polonès com a L1. Concretament, ens centrarem en l'adquisició de les estratègies de cortesia associades a la formulació de dos actes de parla: les peticions i els oferiments. La nostra hipòtesi és que la interllengua d'aquests aprenents de català estarà regida no només per regles que tenen a veure amb la L1 dels aprenents, sinó també per regles relacionades amb altres factors.

\section{Metodologia}

\subsection{Informants}

Vint-i-tres informants varen respondre el qüestionari, 13 dels quals tenien el polonès com a L1 i eren aprenents de català (català LE) i 10 tenien el català com a llengua inicial (català L1), el grup de control. El grup d'informants aprenents de català com a LE el vàrem subdividir, al seu torn, en dos grups segons el nivell de català acreditat pel Marc Europeu Comú de Referència (MECR). Així doncs, 8 informants tenien el nivell B1 i 5 informants el nivell B2. La mostra estava esbiaixada pel que fa al gènere, ja que 18 dels informants s'identificaren com a dones i només 5 com a homes. Pel que fa a l'edat, 12 informants pertanyien al grup d'edat de 18-25 anys, 3 al de 26-35 anys i 8 al de 35-50 anys.

A més de la tasca de compleció del discurs, els informants també varen haver de contestar un qüestionari sobre el seu historial lingüístic, en què se'ls demanava quina va ser la llengua que varen adquirir a casa, quina la d'instrucció a l'educació secundària i a la universitat, la freqüència amb què usen el català amb els amics, la família i a la feina o la universitat $i$, finalment, amb quina freqüència pensen o reflexionen en català. Pel que fa a la llengua que aprengueren a casa, els resultats demostraren que un 90\% del grup d'informants amb L1 català varen aprendre català a casa i un $90 \%$ dels informants amb el català com a LE hi varen aprendre el polonès. La llengua d'instrucció en l'educació secundària va ser majoritàriament 
el català per als informants L1 català (80\%) i el polonès per als informants LE català $(76,9 \%)$. La llengua d'instrucció a la universitat per als L1 català va ser el català en un 50\%, el castellà en un $20 \%$ i l'anglès en un $30 \%$. Pel que fa als informants LE català, la llengua d'instrucció a la universitat va ser el polonès i el castellà en un $46,2 \%$ dels casos, només el castellà en un $30,8 \%$, només el polonès en un $15,4 \%$ i, finalment, el polonès, el castellà i el català en un $7,7 \%$. Cal precisar que quasi tots els informants LE català eren estudiants del grau de Filologia Espanyola de la Universitat Adam Mickiewicz de Poznań (Polònia). Això explica que el castellà hi tengui una presència tan important. A més, és important afegir que alguns estudiants, abans d'entrar a la universitat, ja varen estudiar en un liceu o centre d'ensenyament secundari on l'espanyol s'ensenyava com a llengua estrangera. És per això que només 3 de cada 4 informants LE català, i no tots, havien tengut el polonès com a llengua d'instrucció a l'educació secundària. Finalment, pel que fa a l'ús del català, els informants amb el català com a llengua inicial l'usen amb els amics, la família i per pensar o reflexionar més d'un 75\% del temps. En canvi, la majoria l'usa només entre un $45 \%$ i un $75 \%$ en l'àmbit laboral o universitari. Quant als informants amb el català com a LE, vàrem veure que l'usaven menys d'un $25 \%$ del temps per parlar amb els seus amics (suposam que aquests amics són de l'àmbit universitari). Com era d'esperar, el català no s'usa en l'àmbit familiar, però sí en el laboral/universitari. Així doncs, 6 dels 13 informants amb el català com a LE l'usa menys d'un 25\%, 4 entre un $45 \%$ i un $75 \%$ i 3 entre un $25 \%$ i un $45 \%$. Finalment, 8 dels 13 informants polonesos usen el català menys d'un $25 \%$ del temps quan pensen o reflexionen.

\subsection{Materials}

El tipus de mètode utilitzat va ser una adaptació del qüestionari dissenyat per Astruc, Vanrell i Prieto (2016), basat en la tasca de compleció del discurs o TCD (veg. Vanrell, Feldhausen i Astruc, 2018 per a una revisió aprofundida de la tasca). Mitjançant aquest mètode es varen recollir un total de 362 enunciats.

La TCD consisteix a plantejar una sèrie de situacions als informants a les quals han de respondre de la manera més natural possible. És imprescindible que els entrevistats responguin utilitzant la imaginació. Per això, la tasca de l'investigador és motivar tant com pugui la immersió dels informants en una situació determinada per tal d'obtenir dades tan espontànies com sigui possible.

El qüestionari constava de tres seccions: informació biogràfica, historial lingüístic i la tasca de compleció del discurs. La TCD estava formada per 16 situacions diferents (8 peticions i 8 oferiments). A l'hora de dissenyar les situacions es varen manipular les següents variables:

1. El poder social del destinatari del missatge amb relació al de l'emissor: $[-\mathrm{P}] \mathrm{o}[+\mathrm{P}]$.

2. La distància social entre l'emissor i el destinatari: $[-\mathrm{D}] \mathrm{o}[+\mathrm{D}]$.

3. El cost, entès com a cost-benefici de l'acció verbal per al destinatari: $[-\mathrm{C}] \mathrm{o}[+\mathrm{C}]$.

Les situacions (3) i (4) són dues mostres de les situacions exposades en el qüestionari. Es tracta de dues situacions fictícies creades amb l'objectiu d'obtenir, per part dels informants, peticions (3) i oferiments (4) semiespontanis.

(3) Imagina't que és l'aniversari del teu nebot i que ajudes el teu germà o germana a preparar un dinar de família. Comenceu a preparar el dinar sense cap pressa, encara teniu molt de temps. A tu et toca fer les postres, pastís de llimona. Esteu a la cuina, treballant tots dos al taulell, i tu necessites un parell de llimones per començar a fer el pastís. Veus que el teu germà les té a la vora. Com les hi demanaries? Petició esperada: Pots donar-me un parell de llimones?

(4) Imagina't que estàs dinant en una cafeteria. Mentre esperes el cafè veus que a la taula del costat hi ha un senyor que busca l'oli. El senyor té uns 70 anys i cabell blanc, i sembla 
que té pressa. Tu ja no el necessites i penses que potser aquest senyor el voldria i l'hi ofereixes. Com li ho diries?

Oferiment esperat: Perdoni, necessita l'oli? Ara l'hi pas.

A la situació (3) l'informant ha de demanar (petició) un parell de llimones al seu germà. Per tant, no hi ha diferència de poder entre els dos parlants i la distància i el cost són baixos perquè el destinatari és un familiar i només es tracta de passar unes llimones, acció que requereix poc cost per a l'interlocutor i poc benefici per al parlant que formula la petició. A la situació (4), l'informant ha d'oferir (oferiment) el setrill d'oli que està utilitzant a un senyor d'uns 70 anys. Per tant, en aquesta situació no hi ha diferència de poder i la distància social és alta perquè es tracta d'un desconegut. El cost de l'acció continua sent baix, ja que es tracta només de passar un setrill d'oli.

\subsection{Procediment}

Els qüestionaris es varen elaborar mitjançant l'eina Formularis de Google. Les dues versions eren en català central. Per poder distribuir el qüestionari entre els informants polonesos vàrem contactar amb la professora de llengua catalana de la Universitat Adam Mickiewicz de Poznań (Polònia) durant el curs 2018/2019, mentre que per distribuir-lo entre els informants catalans simplement es va enviar a amics i coneguts.

Amb la tasca de compleció del discurs es varen recollir 368 enunciats (16 enunciats x 23 informants). Cal tenir en compte que hi va haver 6 respostes en blanc per part dels participants. Per tant, la base de dades final constava de 362 enunciats. A continuació, es varen introduir a un full d'Excel i, després, es varen processar amb el programa SPSS per poder aplicar l'estadística descriptiva i inferencial. Les variables analitzades varen ser les següents:

a. Variables dependents: ús de preguntes (dos nivells: sí o no); el temps verbal (cinc nivells: present, imperfet, condicional, imperatiu i altres); el tractament (dos nivells: tu i vós/ vostè); la mitigació (dos nivells: sí o no); i el tractament senyor (dos nivells: sí o no).

b. Variables independents: el tipus d'acte de parla (dos tipus: peticions o oferiments); el poder social del destinatari del missatge en relació amb l'emissor (dos nivells: menys i més poder); la distància social entre l'emissor i el destinatari (dos nivells: menys i més distància); i el cost de l'acció verbal per al destinatari (dos nivells: menys i més cost).

Com hem dit, l'estadística inferencial també es va aplicar mitjançant el programa SPSS. En general, es varen fer dos tipus de tests no paramètrics: el test de Wilcoxon i el test de KruskalWallis. La prova de Wilcoxon es va usar per contrastar dues mostres aparellades, és a dir, l'efecte de dues condicions en un mateix grup d'individus. Exemple: l'efecte del tipus d'acte de parla, en aquest cas els oferiments i les peticions, en l'ús o no d'interrogatives per part dels informants. En canvi, la prova de Kruskal-Wallis es va aplicar per comparar l'efecte d'una mateixa condició en tres o més grups experimentals diferents. Per exemple: l'efecte d'un tipus d'acte de parla concret, els oferiments, en l'ús o no d'interrogatives per part dels informants amb el català com a L1, els informants amb el català com a LE (nivell B1) i els informants també amb el català com a L2 (nivell B2). Només s'han aplicat els tests quan la grandària de la mostra ho ha permès. Per tant, quan no es presenten resultats estadístics és perquè no s'han pogut aplicar, no perquè les diferències no siguin estadísticament significatives. 


\section{Resultats}

A continuació presentam els resultats obtinguts en l'anàlisi de les dades recollides mitjançant la TCD i tenint en compte cadascuna de les variables dependents que intervenen en l'expressió de la cortesia lingüística: l'ús de preguntes, el temps verbal, el tractament o dixi de persona i els mitigadors.

\subsection{Les preguntes}

Com hem vist, en general en català les peticions tendeixen a formular-se més freqüentment mitjançant la modalitat interrogativa que els oferiments (Astruc, Vanrell i Prieto, 2016). En canvi, en polonès, la modalitat interrogativa sol evitar-se tant en les peticions com en els oferiments (Wierzbicka, 2003). El que observam a la figura 1 és que la tendència a formular les peticions més freqüentment mitjançant la modalitat interrogativa es manté en els tres grups d'informants. Curiosament, els parlants de català com a LE, en comparació amb els parlants catalans, tendeixen a produir lleugerament menys interrogatives en els oferiments. Cal destacar que dels dos grups de parlants amb el català com a LE, el que produeix interrogatives en un percentatge més baix en els oferiments és el que té el nivell acreditat de català més alt, és a dir, el nivell B2. Segons la prova de Wilcoxon, l'efecte del tipus d'acte de parla sobre la producció d'interrogatives és estadísticament significatiu per als tres grups de parlants: $\mathrm{L} 1$ català $(T=12,50, r=-.22, \mathrm{p}<, 005)$, LE català amb el nivell $\mathrm{B} 1(T=10, r=\mathrm{X}-.35$, $p<, 001)$ i LE català amb el nivell B2 $(T=10,50, r=-.39, p<, 001)$. En canvi, però, segons el test de Kruskal-Wallis no hi ha diferències, pel que fa a la realització d'interrogatives en els oferiments i les peticions, entre els tres grups d'informants $(H(2)=3,5, p>, 1)$.

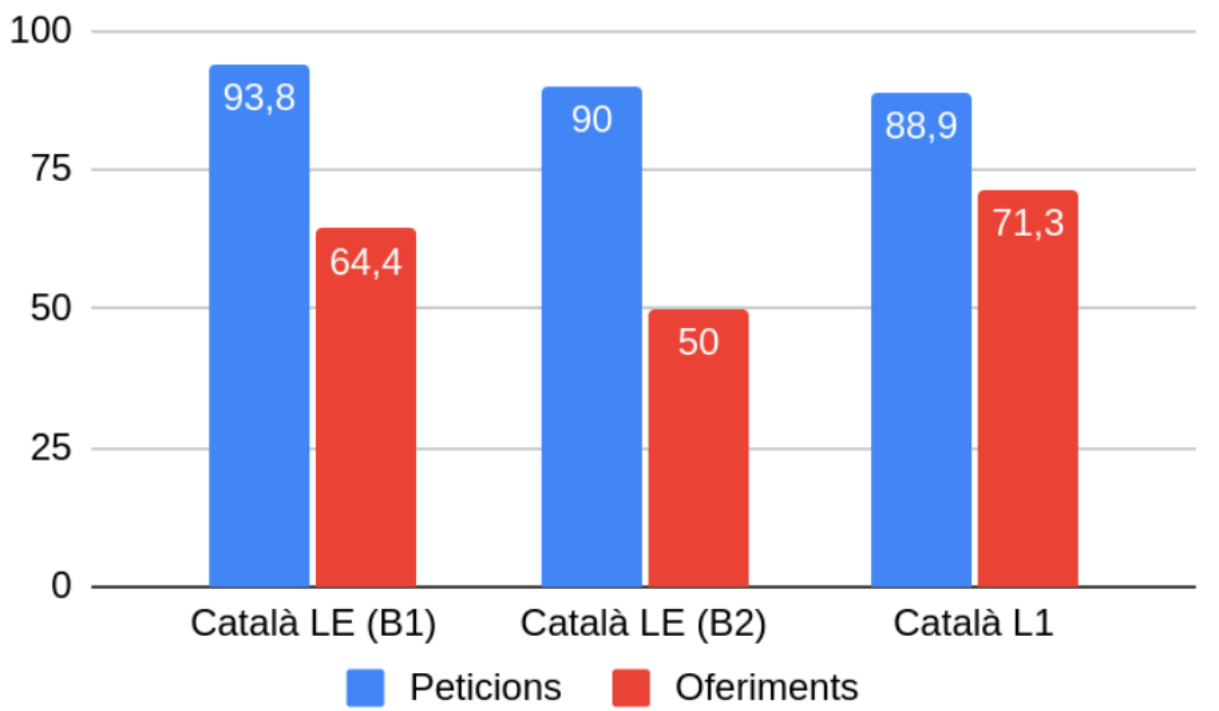

Figura 1. Percentatge de preguntes en peticions i oferiments segons el nivell de català dels informants (B1, B2 o L1).

Pel que fa als factors pragmàtics com el poder del receptor, la distància social entre l'emissor i el receptor i el cost de l'acció per al receptor, hem observat que sobretot la distància i el cost són els factors que tenen un impacte més gros sobre la producció d'interrogatives. La distància social té un efecte més important en els oferiments que en les peticions (figura 2), de manera que a més distància social entre l'emissor i el receptor, més s'incrementa l'ús de preguntes. Si comparam el grup d'informants amb el català com a L1 amb els qui el tenen com a LE, observam que novament els dos darrers grups són els que menys recorren a les interrogatives quan la distància social és baixa. Trobam, també, un efecte del cost de l'acció per al destinatari en la producció de les interrogatives, tot i que menys sistemàtic. Així doncs, observam un efecte de l'increment del cost en la producció de més interrogatives només en les peticions i només en els parlants amb L1 català o amb LE català amb un nivell més alt de competència (B2). 


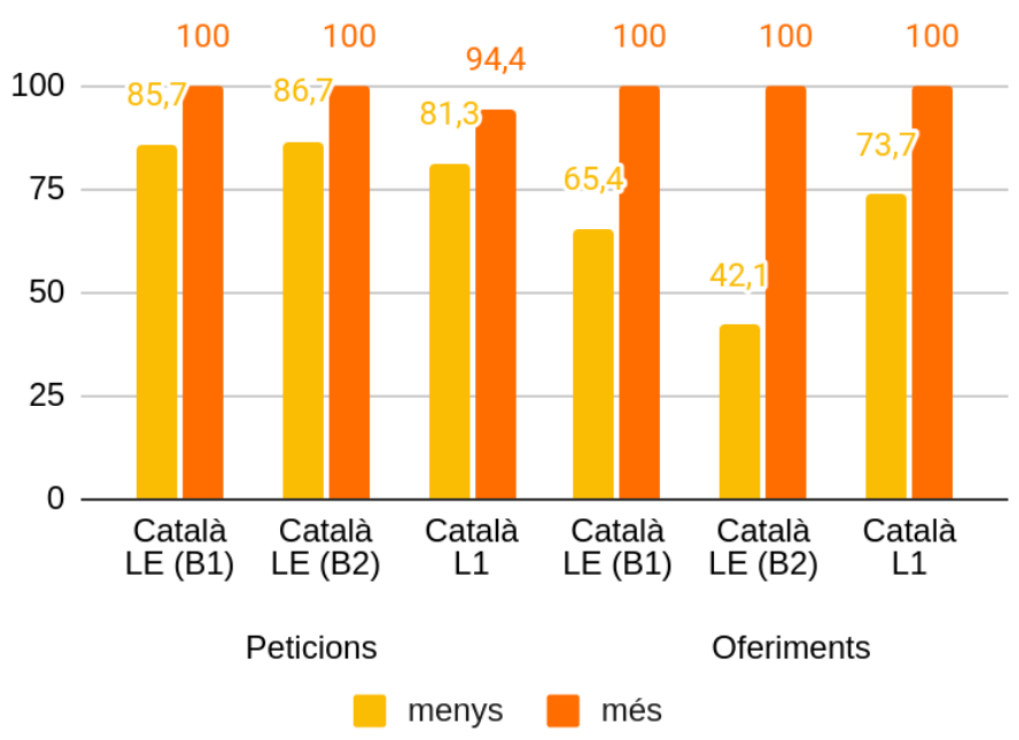

Figura 2. Percentatge de preguntes en peticions i oferiments tenint en compte la distància social i el nivell de català dels informants (B1, B2 o L1).

\subsection{El temps verbal}

L'ús dels temps verbals que es corresponen amb un llenguatge indirecte, com ara l'imperfet d'indicatiu o el condicional, s'ha relacionat amb la vehiculació de més cortesia. Si observam la figura 3, veim que en les peticions, acte de parla inherentment descortès, la tendència és a usar un temps verbal no directiu com ara el condicional. En segona posició trobam l'ús del present d'indicatiu i, molt per baix, l'imperatiu. Cal destacar que els parlants amb el català com a LE recorren més freqüentment a temps verbals no directius comparats amb els parlants amb el català com a L1. Tanmateix, segons el test de Kruskal-Wallis, aquestes diferències que trobam entre els tres grups de parlants no són significatives $(H(2)=3,24, \mathrm{p}>, 1)$.

En els oferiments (figura 4), en canvi, la tendència és a usar, gairebé exclusivament, el present d'indicatiu. En segona posició hi trobam el condicional. No hi ha diferències significatives entre els tres grups de parlants, com ja es percep a la figura $4(H(2)=1,02, p>, 5)$. No obstant això, segons el test de Wilcoxon, sí que trobam diferències estadísticament significatives entre les tries verbals que fa cada grup en les peticions en comparació amb els oferiments, cosa que ja es percep si comparam la figura 3 amb la figura 4: català L1 $(T=7,50, r=-.34, p<, 001)$, català LE, nivell $\mathrm{B} 1(T=55, r=-.45, p<, 001)$, i català LE, nivell $\mathrm{B} 2(T=29, r=-.50, p<, 001)$.

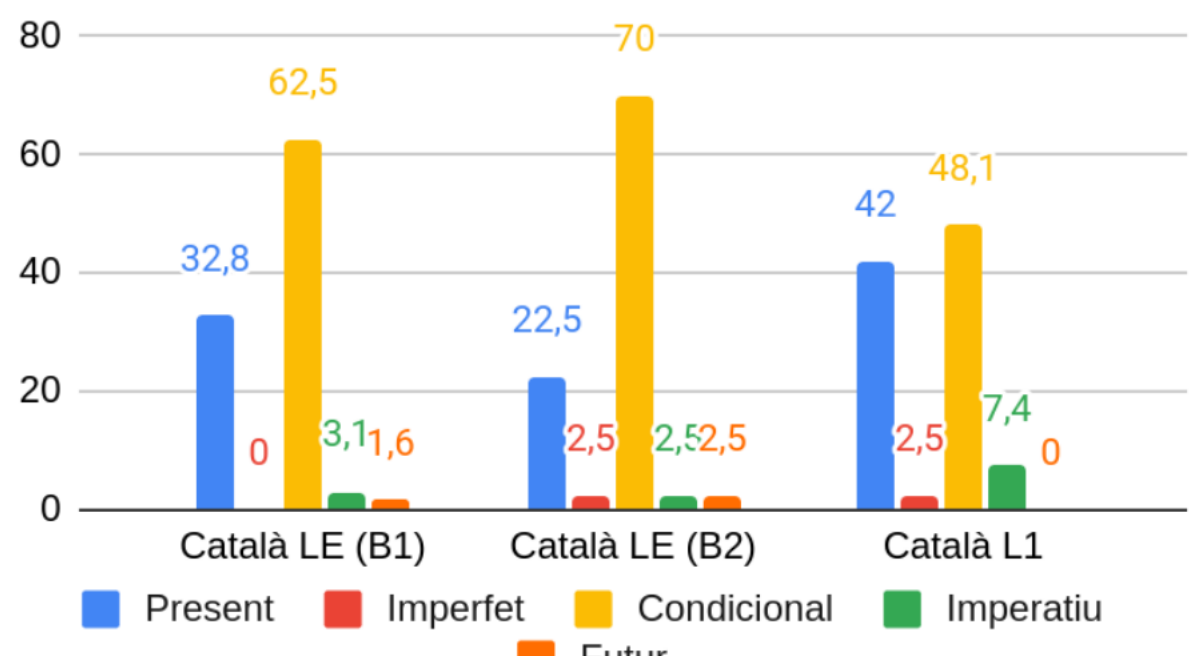

Figura 3. Percentatge de temps verbals en les peticions segons el nivell de català dels informants (B1, B2 o L1). 


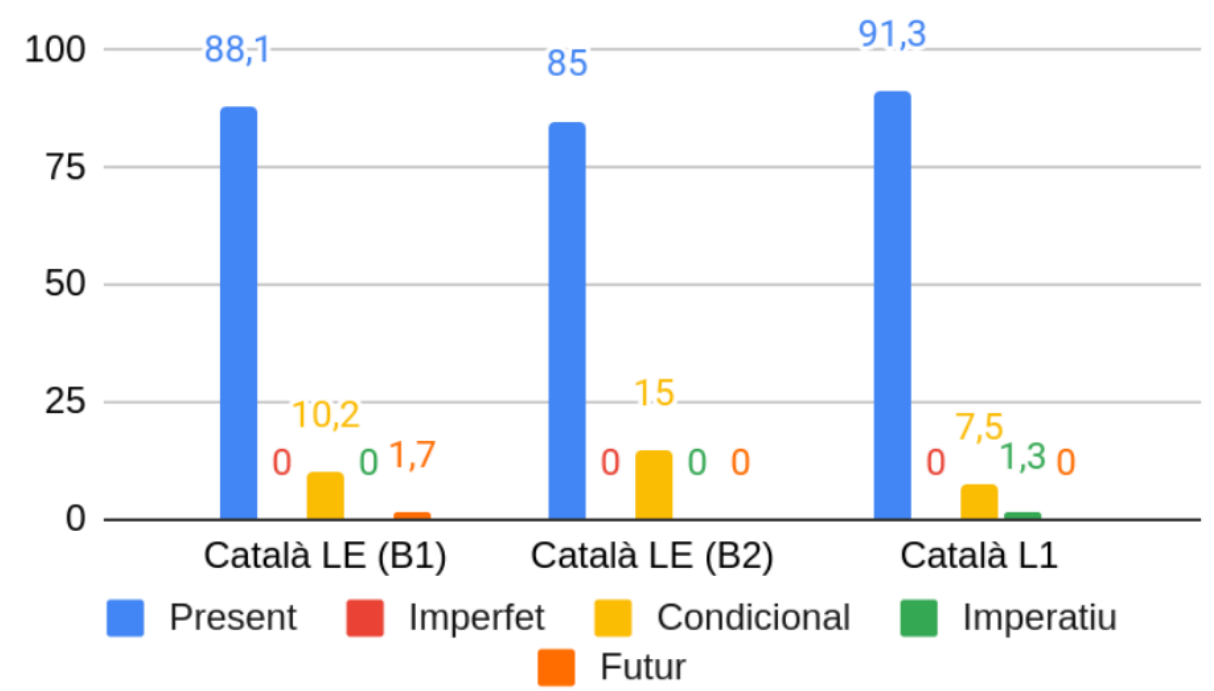

Figura 4. Percentatge de temps verbals en els oferiments segons el nivell de català dels informants (B1, B2 o L1).

\subsection{La dixi de persona}

En català tant l'acte de parla (peticions i oferiments) com factors pragmàtics com la distància i el poder socials s'han relacionat amb un increment en l'ús dels pronoms de cortesia vós/vostè (Astruc, Vanrell, Prieto, 2016; Pizà i Vanrell, 2018). En polonès trobam una diferència entre el pronom ty 'tu', usat quan hi ha menys distància entre els interlocutors, i el tractament Pan/Pani 'senyor/senyora', que s'usa quan hi ha més distància (Wierzbicka, 2003). Tanmateix, no sabem si altres factors pragmàtics com el poder de l'interlocutor i el cost de l'acció poden tenir un efecte sobre l'ús de la dixi de persona.

D'entrada veim (figura 5) que els informants L1 català tendeixen a fer un ús més freqüent del pronom $t u$ que els informants LE català. L'efecte de l'acte de parla en el tipus de tractament utilitzat és poc important i apareix només en les peticions i en parlants que tenen el català com a LE. L'efecte del poder social del receptor torna a ser poc sistemàtic, però, en canvi, sí que veim un efecte més important de la distància tant en les peticions com en els oferiments (figures 6 i 7) i del cost sobretot en les peticions (figura 8). En les figures 6 i 7 veim que a més distància social entre l'emissor i el receptor, més freqüent és l'ús dels pronoms de cortesia vós/vostè. En les peticions, el cost de l'acció verbal i la llengua inicial interactuen i els dos afecten la dixi de persona. Com podem observar a la figura 8, només els parlants polonesos tendeixen a produir més pronoms de cortesia quan el cost de l'acció és més alt.

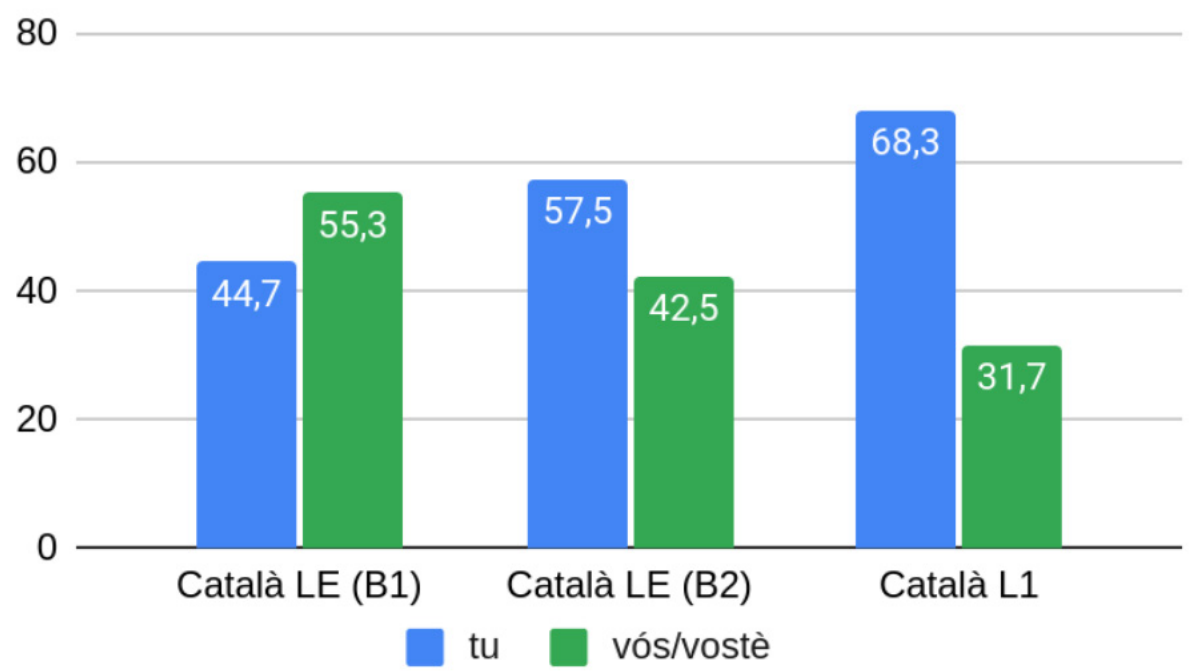

Figura 5. Percentatge dels tractaments tu i vós/vostè segons el nivell de català dels informants (B1, B2 o L1). 


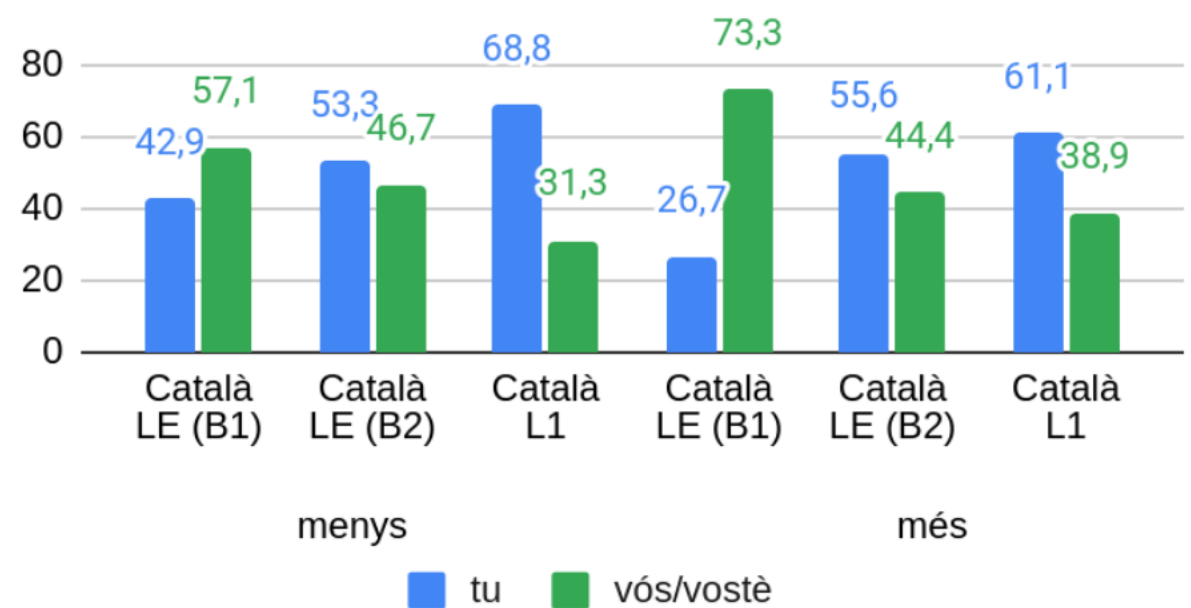

Figura 6. Percentatge dels tractaments tu i vós/vostè segons la distància, en les peticions, tenint en compte el nivell de català dels informants (B1, B2 o L1).

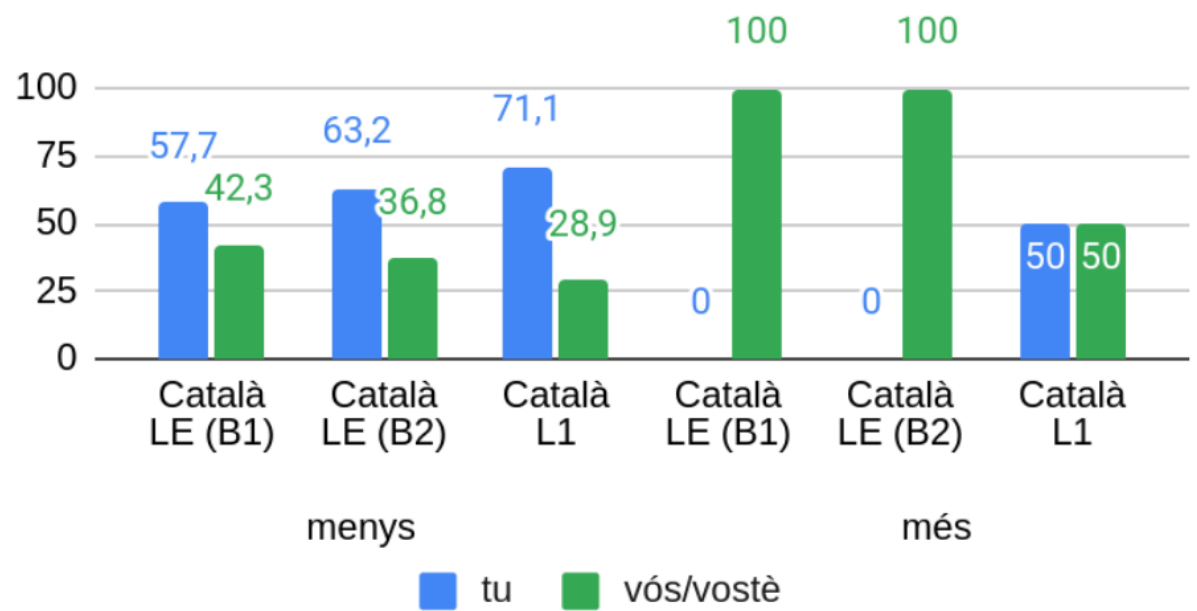

Figura 7. Percentatge dels tractaments tu i vós/vostè segons la distància, en els oferiments, tenint en compte el nivell de català dels informants (B1, B2 o L1).

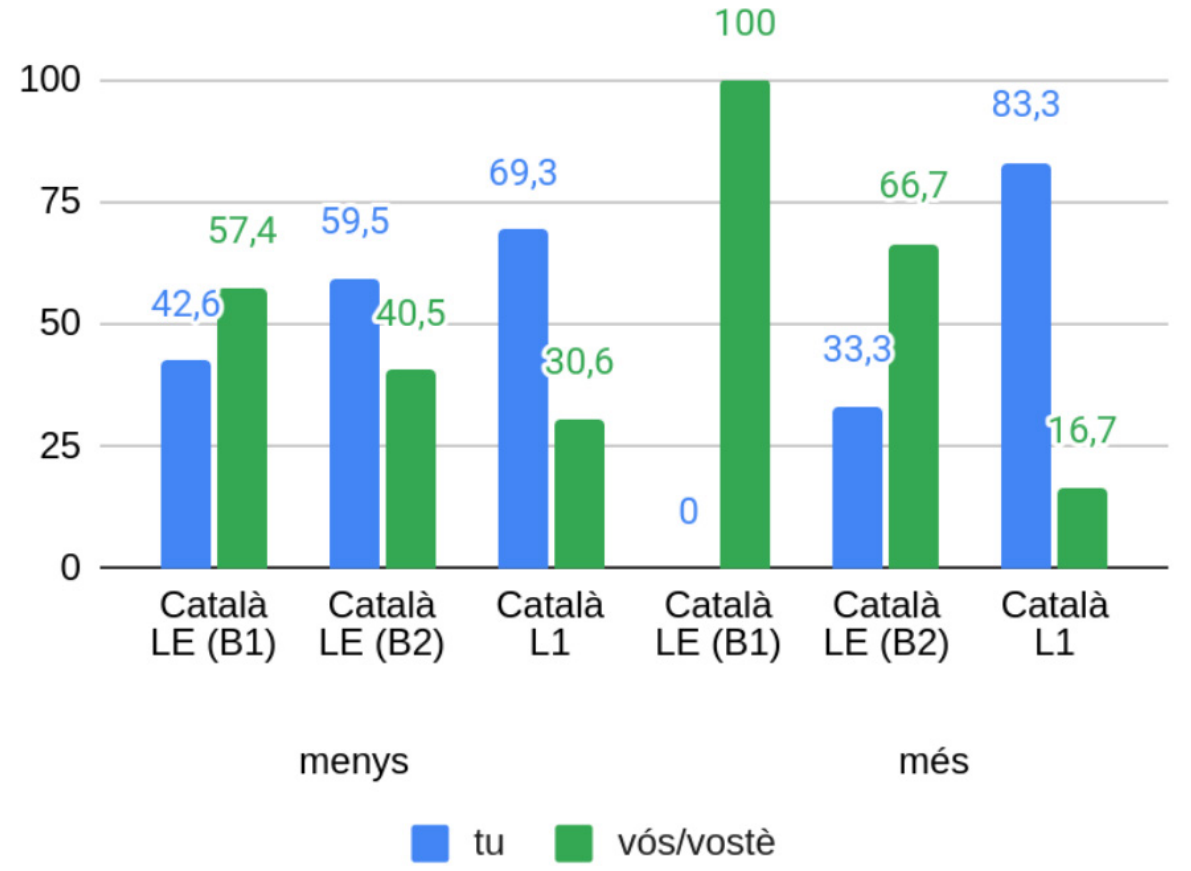

Figura 8. Percentatge dels tractaments tu i vós/vostè segons el cost, en les peticions, tenint en compte el nivell de català dels informants (B1, B2 o L1). 
Un altre resultat important és el que té a veure amb l'ús del tractament de cortesia senyor/ senyora, l'equivalent al Pan/Pani polonès. Com veim a la figura 9, en contraposició amb els parlants que tenen el català com a L1, els parlants polonesos empren el tractament senyor/ senyora, especialment en les peticions. Curiosament, els qui més l'usen són els parlants que tenen un nivell acreditat de català més alt, és a dir, els qui tenen el B2.

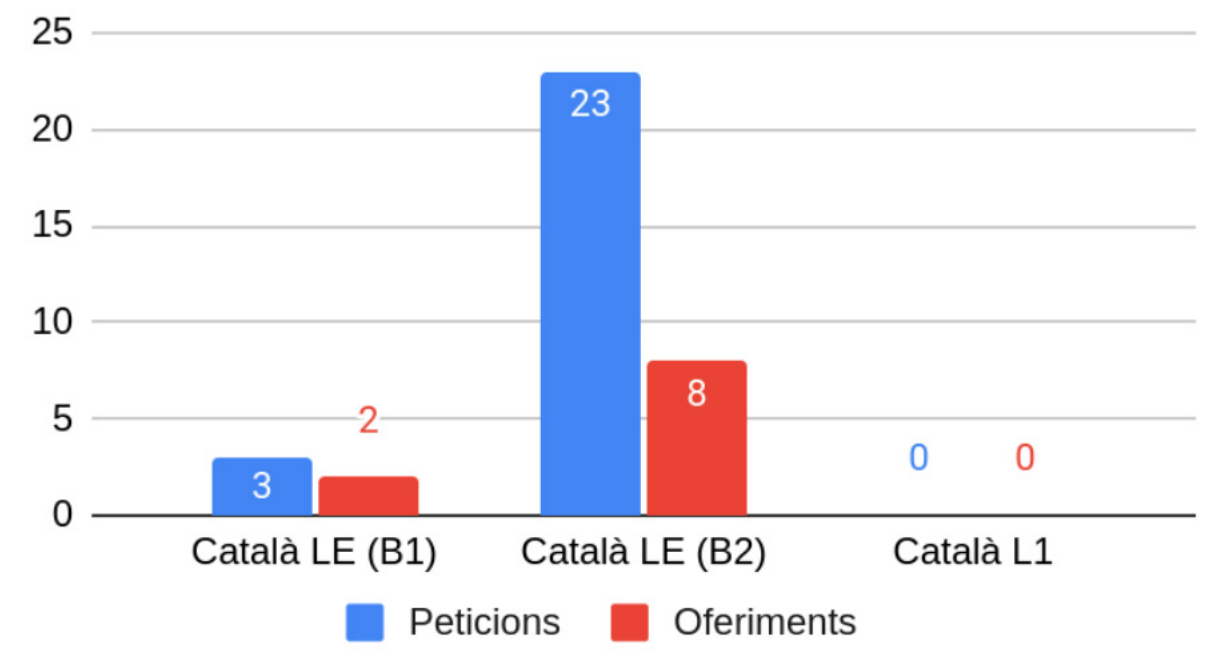

Figura 9. Percentatge del tractament senyor en les peticions

i els oferiments segons el nivell de català dels informants (B1, B2 o L1).

\subsection{Els mitigadors}

La noció de mitigació s'ha usat per fer referència al conjunt d'estratègies emprades pels interlocutors per atenuar l'impacte del que Brown i Levinson (1987) anomenen accions que amenacen la imatge pública (veg. Introducció). S'han proposat diferents tipus de mitigació. En aquest treball, hem partit de la classificació de Fraser (1990: 345-349). Val a dir, però, que no hem fet una classificació sistemàtica de les diferents estratègies de mitigació usades pels informants, sinó que simplement s'ha etiquetat si feien ús d'algun mecanisme de mitigació o no. Fraser (1990), apud Ali i Salih (2020), distingeix set tipus d'estratègies de mitigació: els actes de parla indirectes (I would appreciate it if I were left alone 'Agrairia poder estar $\mathrm{sol}^{\prime 3}$ ), construccions impersonals (FAA regulations require that all passengers fasten their seat belts 'El reglament de la FAA requereix que tots els passatgers es cordin el cinturó de seguretat'), exoneracions (Unless I'm mistaken about the situation, the plane is total loss 'Si no m'equivoc, l'avió es troba en situació de sinistre total'), verbs parentètics (This is the road, I guess 'La carretera és aquesta, m'imagín'), preguntes confirmatòries amb cua (You were there, weren't you? 'Tu eres allà, no és ver?'), mots mitigadors com ara verbs modals, adjectius de probabilitat, aproximadors, clàusules amb si, etc. (Such a measure might be more sensitive to changes in health after specialist treatment 'Una mesura com aquesta, després del tractament d'un especialista, pot ser més sensible a canvis en la salut') i eufemismes com escurçaments, circumloquis, canvis semàntics, etc. (solid human waste 'residus sòlids humans' pot ser un eufemisme per circumloqui de faeces 'femta').

Segons veim a la figura 10, els parlants usen lleugerament més mitigadors en les peticions que en els oferiments. Pel que fa a l'efecte dels factors pragmàtics com el poder social del receptor, la distància entre els interlocutors i el cost de l'acció per al destinatari, observam a la figura 11 que el cost és el factor que té un efecte més sistemàtic, per bé que poc important, en l'ús de mecanismes de mitigació. Com il-lustra la figura 11, la tendència és a emprar més mitigadors en les peticions d'accions que tenen més cost (esquerra). Aquesta tendència és més

3 Les traduccions al català són nostres. 
acusada en els parlants amb el català com a L1. En canvi, en els oferiments (dreta) s'observa la tendència contrària, és a dir, els oferiments d'accions amb menys cost per al destinatari són els que presenten més mitigadors.

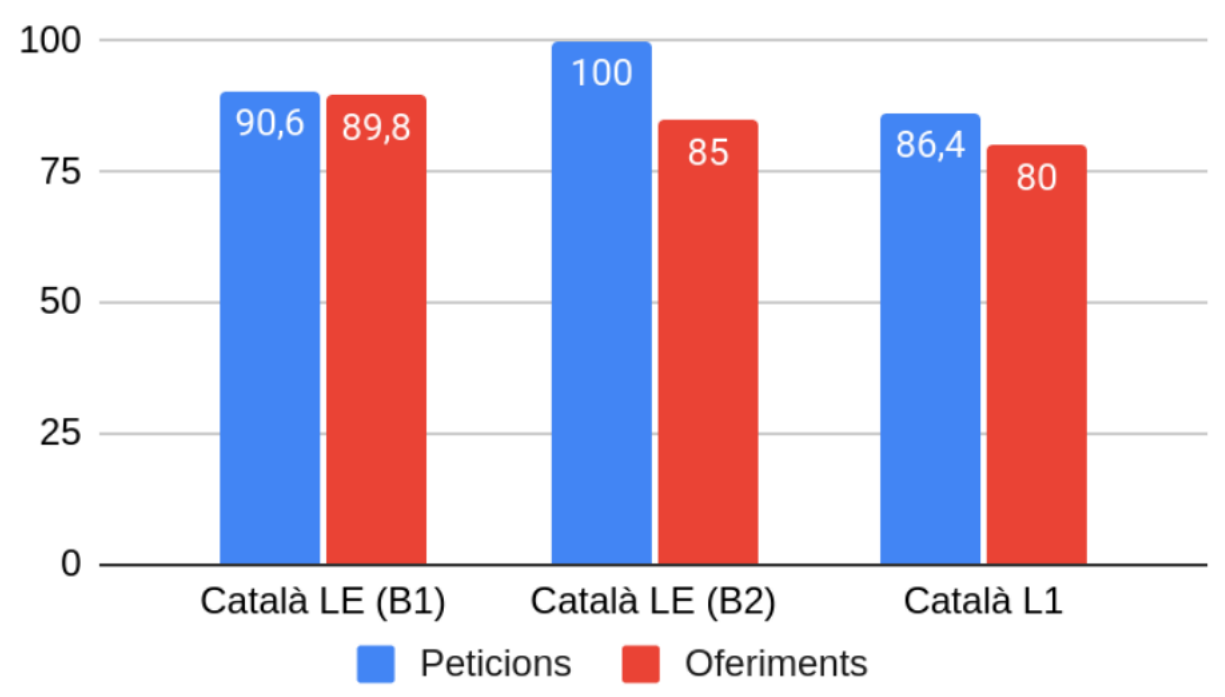

Figura 10. Percentatge d'ús de mitigadors en peticions i oferiments segons el nivell de català dels informants (B1, B2 o L1).

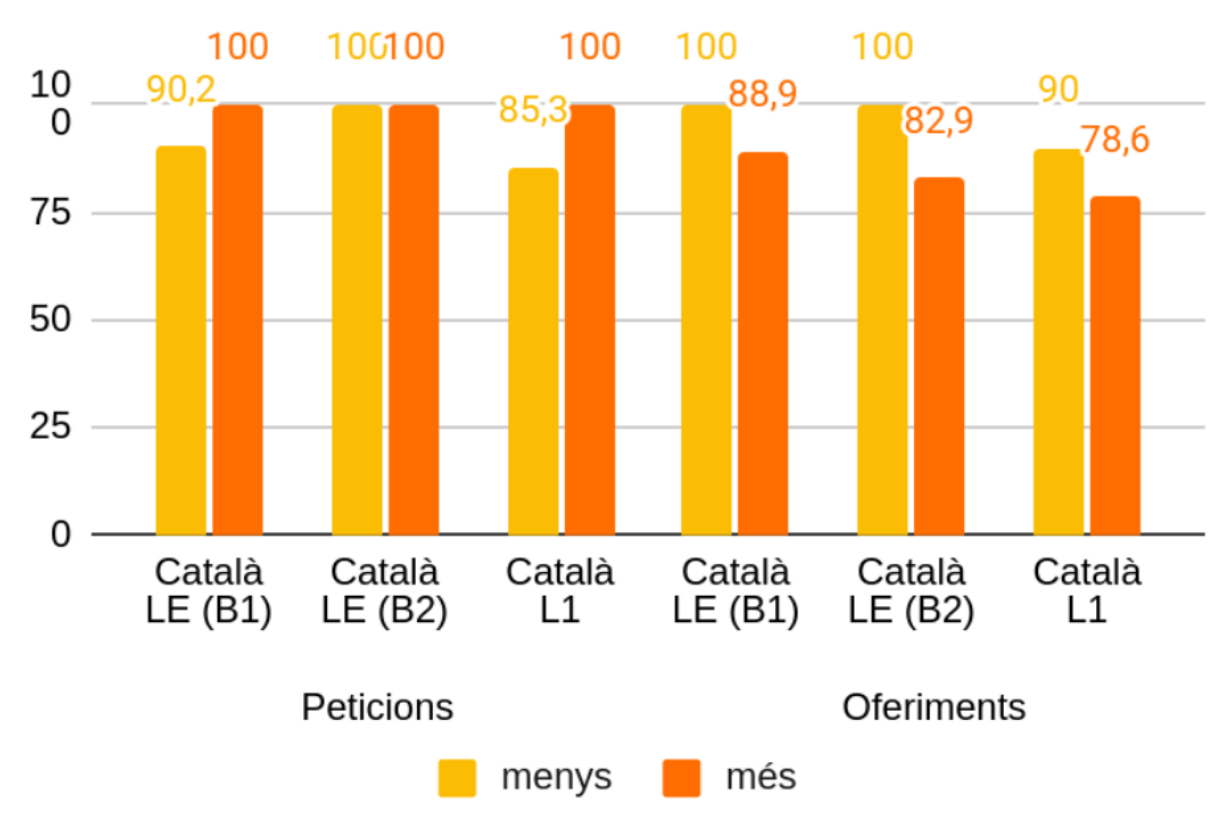

Figura 11. Percentatge de mitigadors en peticions i oferiments tenint en compte el cost i el nivell de català dels informants (B1, B2 o L1).

\section{Discussió i conclusions}

L'objectiu d'aquest treball era el d'estudiar el desenvolupament de la pragmàtica de la interllengua dels aprenents de català amb el polonès com a L1. Concretament, l'interès se centrava en l'adquisició de les estratègies de cortesia associades amb les peticions i els oferiments. Amb aquest objectiu es va crear un qüestionari basat en la tasca de compleció del discurs usada a Astruc, Vanrell i Prieto (2016), que es va distribuir entre 23 informants (13 parlants de català com a LE i 10 parlants de català com a L1). Les variables dependents analitzades han estat l'ús de preguntes (dos nivells: sí o no), el temps verbal utilitzat (cinc nivells: present, imperfet, condicional, imperatiu i altres), el tipus de tractament utilitzat 
(dos nivells: tu i vós/vostè, en el cas dels informants polonesos també es va codificar l'ús del tractament Pan/Pani 'senyor/senyora') i la presència d'estratègies de mitigació (dos nivells: sí o no). Les variables independents controlades varen ser el tipus d'acte de parla (dos tipus: peticions o oferiments), el poder social del destinatari del missatge amb relació a l'emissor (dos nivells: menys i més poder), la distància social entre l'emissor i el destinatari (dos nivells: menys i més distància) i el cost de l'acció verbal per al destinatari (dos nivells: menys i més distància). A continuació, es discutiran els resultats segons les variables dependents que s'han analitzat.

Pel que fa a l'ús de la modalitat interrogativa a l'hora de formular una petició o un oferiment, el que hem vist (figura 1) és que les peticions es formulen més freqüentment que els oferiments amb una interrogativa, independentment de quina sigui la llengua inicial o el nivell de català acreditat (5). En canvi, en els oferiments, hi trobam una disminució de les preguntes, sobretot en el cas dels parlants polonesos (6). Aquesta diferència entre els parlants que tenen el català com a L1 i els qui hi tenen el polonès, per bé que no és estadísticament significativa, podria interpretar-se com un cas de transferència negativa del polonès, atès que aquesta llengua tendeix a evitar les interrogatives, especialment en els oferiments (veg. Introducció). Altres factors que poden tenir un efecte en la realització d'aquests actes de parla en forma d'interrogativa són la distància social i el cost. En línies generals, podem dir que la distància afecta més els oferiments, mentre que el cost repercuteix més clarament en les peticions. D'aquesta manera, els oferiments en què hi ha una distància alta entre els interlocutors presenten més freqüentment interrogatives. El mateix succeeix en les peticions en què el cost de l'acció és més alt. Aquests resultats són vàlids sobretot per als parlants de català com a L1 o els aprenents amb un nivell B2 acreditat. ${ }^{4}$

(5) a. Et volia demanar un favor per demà? Podries acostar-me a la feina demà per poder arribar a l'hora? Amb això de la vaga em fa por arribar tard. (català L1)

b. Em passes aquestes llimones? (català LE, nivell B1)

c. Perdona, senyor, podria prendre el seu oli d'oliva? (català LE, nivell B2)

(6) a. Si vols, t'apropo en cotxe a la feina. (català L1)

b. Puc donar-te la melmelada, si vols. (català LE, nivell B1)

c. Joan, jo torno cap l'oficina, si vols anem junts amb el cotxe. (català LE, nivell B2)

Quant a l'ús de diferents temps verbals, veim una diferència important entre les peticions i els oferiments. En les peticions hi trobam un ús més elevat de temps verbals no directius, com ara el condicional (7a), mentre que en els oferiments hi trobam sobretot l'ús del present (7b). Una altra dada important és que els informants polonesos en general tendeixen a emprar més temps no directius, com el condicional, que els parlants catalans.

(7) a. Perdona, et faria res portar-me en cotxe? (català L1)

b. Senyor, li paso l'amanida, si vol. (català LE, nivell B2)

Els parlants de català com a L1 han usat més freqüentment el pronom tu de mitjana que els pronoms de cortesia. En canvi, els parlants polonesos han fet un ús més equilibrat del $t u$ i els pronoms de cortesia. L'acte de parla sembla no tenir un efecte gaire important en l'ús dels diferents tractaments. Pel que fa als factors pragmàtics, només la distància i el cost condicionen la tria del pronom. El cost és especialment important per als parlants polonesos. Finalment, cal destacar l'ús preferent del tractament senyor/senyora per part dels parlants polonesos (8). Val la pena dir que són els parlants amb un nivell més alt de català acreditat els qui empren amb més freqüència aquest tipus de tractament (figura 9).

(8) a. Perdó, senyor, l'importaria prestar-me l'oli per un moment? (català LE, nivell B1)

b. Perdó, senyor, es una situació força difícil per a mi per arribar a la feina $i$ voldria

preguntar-li si hi ha possibilitat que demà anirem junts en el seu cotxe? (català LE, nivell B2)

4 Els exemples extrets dels textos s'han transcrit literalment sense fer-hi cap tipus de correcció. 
Finalment, una altra de les variables dependents analitzades ha estat l'ús d'estratègies de mitigació. Tot i que no s'ha fet una anàlisi detinguda dels diferents mecanismes de mitigació, sí que s'ha codificat si el parlant en qüestió n'emprava o no. Els resultats demostren un ús lleugerament més alt de mitigadors en les peticions que en els oferiments. Dels tres grups d'informants, els qui tenen el català com a L1 són els qui més sovint usen els mitigadors, especialment en accions que requereixen un cost alt per al destinatari. Com veim a (9a), un parlant amb el català com a L1 empra diferents estratègies de mitigació. Per començar, usa una construcció impersonal com a tècnica de distanciament: la vaga d'autobusos és un esdeveniment que no depèn ni del parlant ni de l'oient. A continuació, usa una construcció d'exoneració (et faria res) i finalment una clàusula condicional introduïda per si (si no t'he de fer anar malament). A (9b), un parlant polonès amb un nivell B2 de català acreditat usa estratègies de mitigació diverses: exoneracions (perdó) i ús de verbs modals (no vull causarli cap problema, li importaria). A més, el parlant destaca que l'acció no suposa un cost per a l'interlocutor perquè, de fet, viuen en el mateix barri.

(9) a. Escolta, demà hi ha vaga de busos. Oi que vas a Salou? Et faria res que vingués amb tu, si no t'he de fer anar malament? (català L1)

b. Perdó, Director, no vull causar-li cap problema, però li importaria que anessi amb vostè? Com viuem al mateix barri... (català LE, B2)

Si reprenem la hipòtesi general sobre les regles que regeixen la interllengua dels aprenents de català amb el polonès com a L1, en aquest cas, veurem que hem trobat algunes mostres de transferència del polonès al català. La primera mostra té a veure amb l'ús menys freqüent de les interrogatives en els oferiments per part de parlants polonesos en comparació amb els parlants catalans (figura 1), tal com prevèiem a partir de les observacions de Wierzbicka (2003) sobre el polonès. Una altra evidència a favor de la transferència és el fet que els informants polonesos emprin de manera habitual el tractament senyor/senyora, sobretot en les peticions (figura 9). Finalment, una altra mostra d'evidència a favor de la transferència des de la L1, la qual no hem introduït fins ara, és l'ús del verb demanar/preguntar com a estratègia de mitigació. Com explicàvem a la Introducció, en polonès, el verb performatiu prosić (en català: demanar, preguntar) s'empra com a estratègia de cortesia. A (10) s'illlustren alguns exemples amb el verb demanar/preguntar produïts per parlants polonesos.
a. Perdoni, podria demanar la botella d’oli? (català LE, nivell B1)
b. Perdó, senyor, és una situació força difícil per a mi per arribar a la feina i voldria preguntar-li si hi ha possibilitat que demà anirem junts en el seu cotxe? (català LE, nivell B2)
c. Perdoni, queria preguntar si podria una altra vegada anar en cotxe a casa amb usted, si us plau? Ja no tinc cap tren ni autobús per tornar. Però si hi ha algun problema, trobaré una altra opció. (català LE, nivell B1)

Ara bé, també trobam evidència que els aprenents polonesos usen estratègies de cortesia que formen part de la gramàtica de la llengua meta, com ara l'ús del pronom vostè $\left(11^{5}\right)$ en situacions de més distància social i cost, l'ús de temps verbals menys directius com el condicional en actes de parla inherentment descortesos com les peticions (veg. 7), l'ús de preguntes sobretot en les peticions (figura 1) i l'ús de mecanismes mitigadors (veg. 9).
a. Perdoni, podria vostè portar-me a la casa? (català LE, nivell B1)
b. Si vol vostè la meva amanida no hi ha cap problema que li posaria (català LE, nivell B1)

\footnotetext{
5 Els exemples il-lustrats a (11) demostren que en la interllengua dels aprenents també hi trobam indicis de transferència sintàctica de la L1 dels informants. Així, tot i que en català el pronom de cortesia vostè tendeix a aparèixer en posició preverbal en les interrogatives absolutes (Vanrell i Fernández-Soriano, 2014), en els exemples il.lustrats a (11) observam una certa tendència del pronom vostè a ocupar la posició postverbal. Curiosament, en polonès aquesta seria la posició no marcada del tractament Pan/Pani en les interrogatives (comunicació personal de Wojciech Lewandowski, 30 de setembre de 2021).
} 


\section{c. Si voldria vostè que li porti a casa no hi ha cap problema. (català LE, nivell B1)}

d. Perdó, vostè podria passar-me l'amanida? (català LE, nivell B1)

Una dada important és que, contràriament al que podríem pensar, els aprenents de català amb un nivell acreditat més alt, el nivell B2, són els qui en algunes ocasions segueixen estratègies que es diferencien més de la llengua meta i que en alguns casos, fins i tot, són més properes a la llengua de partida, en aquest cas el polonès. Concretament, ens referim a l'ús d'interrogatives en els oferiments (figura 1), dels temps verbals en les peticions (figura 3 ) i del tractament senyor/senyora en les peticions (figura 9). Cal interpretar aquests resultats amb molta cautela, perquè els informants són relativament pocs $i$, per tant, no se'n poden extreure generalitzacions concloents. El que a simple vista podria interpretar-se com a transferència des de la llengua inicial dels aprenents, creim que es tracta d'una major sensibilitat a les estratègies de cortesia disponibles per als parlants. Dit d'una altra manera, els parlants amb un nivell més alt acreditat han desenvolupat una consciència més alta tant cap als recursos disponibles per fer que els enunciats siguin més cortesos (ús d'interrogatives, dixi de persona, mecanismes de mitigació, etc.) com cap als factors que afavoreixen l'ús d'aquests recursos (tipus d'acte de parla, factors pragmàtics com la distància, el poder i el cost, etc.). Això explicaria que, per exemple, aquest grup de parlants fos el que fa un ús més estratègic i més elaborat de determinades variables, en el sentit que usen determinades variables per marcar una diferència entre, per exemple, actes de parla inherentment cortesos i actes de parla inherentment descortesos. Els parlants amb un nivell més baix de català acreditat, en canvi, tendrien més limitats els recursos i, per tant, les estratègies de marcatge de la cortesia serien molt més escasses.

En conjunt, doncs, hem vist que en determinades variables els aprenents polonesos usen alguns recursos que podrien qualificar-se de retencions de la L1, com ara l'ús menys freqüent de les interrogatives en els oferiments, l'ús del tractament senyor/senyora en les peticions i també l'ús freqüent del verb demanar/preguntar. Altres recursos, com ara els temps verbals, la dixi de persona o els recursos mitigadors són gairebé compartits entre aprenents de català i parlants nadius. Les diferències de freqüència entre aprenents més i menys competents s'han interpretat a partir d'una major sensibilitat pragmàtica dels primers que fa que usin tots els recursos disponibles, és a dir, adquirits, a l'hora d'adaptar-se a les diferents situacions comunicatives. Pel que fa als diferents factors que poden tenir un efecte sobre les diferents variables dependents analitzades (ús de preguntes, el temps verbal, els recursos mitigadors i la dixi de persona), hem vist que sobretot per als parlants polonesos els factors més importants són l'acte de parla, és a dir, si es tracta d'una petició o d'un oferiment, i els factors pragmàtics de la distància social entre l'emissor i el destinatari així com el cost de l'acció per al destinatari. En canvi, el poder sembla no tenir cap efecte important. Aquests resultats pel que fa a l'efecte pràcticament nul del poder ja s'havien trobat en treballs anteriors com el d'Astruc i Vanrell (2016), en què aquesta absència d'efecte es va atribuir a la tendència, sobretot en el sector privat, a disminuir les diferències de poder i a tractar tothom com un igual: no rank, we are a team (Astruc i Vanrell: 112). L'acte de parla, doncs, té un efecte sobre la freqüència d'ús de la modalitat interrogativa, més interrogatives en les peticions que en els oferiments; sobre el temps verbal usat, en les peticions s'usen temps verbals més directius; i sobre l'ús d'estratègies mitigadores, ús més freqüent en les peticions. La distància social repercuteix en major mesura en la dixi de persona i, en menor mesura, en la freqüència d'ús de la modalitat interrogativa. El cost de l'acció per al destinatari es contraresta especialment mitjançant la utilització de diferents tipus de mitigadors, però també de pronoms de cortesia (vós/vostè i senyor) i de la modalitat interrogativa. La diferència entre parlants nadius i aprenents de català no és tant una diferència de naturalesa, sinó de grau. Així doncs, veim que els informants polonesos han recorregut més freqüentment a l'ús d'interrogatives o a la dixi de persona a l'hora de suavitzar l'acció mitjançant la cortesia, mentre que tots tres grups usen també 
els temps verbals i diferents tipus de mitigadors. Una vegada més cal insistir que la mostra d'aquest treball era relativament petita. Per poder validar aquests resultats caldria ampliar-la. De moment, doncs, només es tracta d'una primera exploració de la qüestió.

Concloem, per tant, que des del punt de vista pragmàtic la interllengua constitueix un sistema dinàmic, amb un grau alt de variabilitat, però, tanmateix, basat en regles. En el cas concret de les nostres dades, hem vist que podem trobar elements que provenen de la llengua inicial dels parlants, però també en podem trobar d'altres que són generalitzacions o simplificacions de la llengua meta. Com a elements provinents del polonès, hem documentat una disminució de la modalitat interrogativa en els oferiments, l'ús de la forma senyor/senyora en situacions que poden suposar una amenaça a la imatge pública i un ús freqüent del verb performatiu demanar/preguntar. Ara bé, altres estratègies pròpies del català, com ara l'ús del pronom vostè quan hi ha més distància social i cost, de temps verbals menys directius i mecanismes mitigadors en actes de parla inherentment descortesos i de preguntes en les peticions són emprats també de manera extensiva per part dels aprenents de català. Es necessita més recerca per demostrar si aquests patrons illlustren la tendència general i també per esbrinar la causa que determinades estructures de la interllengua segueixin la llengua inicial, mentre que d'altres es prenguin de la llengua meta. Una possible resposta a aquesta darrera pregunta tendria a veure amb la hipòtesi del marcatge pragmàtic discursiu, segons la qual, per exemple, les estratègies indirectes en els actes de parla serien més marcades que les directes, cosa que explicaria per què s'adquireixen més tard en la L1 (Ervin-Tripp, 1977; apud Tran, 2002). Aquestes i altres qüestions es podran reprendre en futures recerques.

\section{Bibliografia}

Ali, A. I. i Salih, S. M. (2020). A Taxonomy of mitigation devices in English language. Koya University Journal of Humanities and Social Sciences, 3(1), 31-40.

Astruc, L., Vanrell, M. M. i Prieto, P. (2016). Cost of the action and social distance affect the selection of question intonation in Catalan. Dins M. E. Armstrong, N. Henriksen i M. M. Vanrell (eds.), Intonational grammar in Ibero-Romance: Approaches across linguistic subfields (pp. 93-113). John Benjamins.

Astruc, Ll. i Vanrell, M. M. (2016). Intonational phonology and politeness in L1 and L2 Spanish. Probus, 28(1), 91-118.

Brown, P. i Levinson, S. (1987). Politeness. Some universals in language usage. Cambridge University Press.

Cicres, J. i Llach, S. (en procés de revisió). L'adquisició de la fonologia del català com a L2. Dins C. Pons-Moll, F. Torres-Tamarit i M. M. Vanrell (eds.), La fonologia del català. Editorial Tirant lo Blanch.

Eckman, F. (1977). Markedness and the contrastive analysis hypothesis. Language Learning, 27(2), 315-330.

Eckman, F. (1985). Some theoretical and pedagogical implications of the markedness differential hypothesis. Studies in Second Language Acquisition, 7(3), 289-307.

Eckman, F. (1991). The Structural Conformity Hypothesis and the acquisition of consonant clusters in the interlanguage of ESL learners. Studies in Second Language Acquisition, 13, 23 41.

Ervin-Tripp, S. (1977). Wait for me, roller-skate! Dins S. Ervin-Tripp. i C. Mitchell-Kernan (eds.), Child discourse (pp. 165-188). Academic Press.

Escandell-Vidal, V. (1996). Introducción a la pragmática. Ariel. 
Escandell-Vidal, V., Estebas-Vilaplana, E. i Vanrell, M. M. (en procés de revisió). La interfície fonologia-pragmàtica. Dins C. Pons-Moll, F. Torres-Tamarit i M. M. Vanrell (Eds.), La fonologia del català. Editorial Tirant Lo Blanch.

Fraser, B. (1990). Conversational mitigation. Journal of Pragmatics, 4(4), 341-350.

Grice, H. P. (1975). Logic and conversation. Dins P. Cole i J. L. Morgan. (Eds.), Syntax and semantics, Vol. 3, Speech acts (pp. 41-58). Academic Press.

Lado, R. (1957). Linguistics Across Cultures. The University of Michigan Press.

Leech, G. (1983). Principles of Pragmatics. Longman.

Meisel, J. M. (1977). The language of foreign workers in Germany. Dins C. Molony, H. Zobl i

W. Stolting. (eds.), Deutsch im Kontakt mit anderen Sprachen (pp. 184-212). Scriptor.

Odlin, T. (1989). Language transfer. Cambridge University Press.

Pizà, M. i Vanrell, M. M. (2018). Dixi de persona i Teoria de la cortesia en el català de Mallorca, dins Actes de les I Jornades d'Estudis Locals de Llucmajor (pp. 837-853). Ajuntament de Llucmajor.

Sánchez, R. (2005). L'àrab. Estudi comparatiu entre la gramàtica del català i la de l'àrab. Generalitat de Catalunya, Departament de Benestar i Família.

Selinker, L. (1972). Interlanguage. International Review of Applied Linguistics, 10, 209-231.

Torres-Tamarit, F. i Vanrell, M. M. (2021). Els universals lingüístics i el marcatge en l'ensenyament de la pronunciació del català com a llengua estrangera. CLIL. Journal of Innovation and Research in Plurilingual and Pluricultural Education, 4(2), 35-48.

Tran, G. Q. (2002). Pragmatic and discourse markedness hypothesis. Proceedings of the 2002 Conference of the Australian Linguistic Society. http://www.als.asn.au/proceedings/als2002/ Tran.pdf

Vanrell, M. M., Feldhausen, I., i Astruc, Ll. (2018). The discourse completion task in romance prosody research: Status quo and outlook. Dins I. Feldhausen, J. Fließbach i M. M. Vanrell (eds.), Methods in prosody: A view from Romance languages (pp. 191-227). Language Science Press.

Vanrell, M. M. i Fernández-Soriano, O. (2014). Dialectal variation at the Prosody-Syntax interface: Evidence from Catalan and Spanish interrogatives. Proceedings of Speech Prosody 2014, 253-282.

Wierzbicka, A. (2003). Different cultures, different languages, different speech acts. Dins W. Winter (Ed.), Cross-cultural pragmatics. The semantics of human interaction (pp. 25-66). De Gruyter.

Winford, D. (2002). An introduction to contact linguistics. Blackwell Publishing 